\title{
How Are Local Policies Promoting Older People's Mobility? A Case Study
}

\author{
Gonçalo Santinha ${ }^{1,2,3}$, Catarina Costa ${ }^{3}$ and Sara Diogo $1,3,4, *$ (D) \\ 1 GOVCOPP_Governance, Competitiveness and Public Policies Research Unit, 3810-193 Aveiro, Portugal; \\ g.santinha@ua.pt \\ 2 CEGOT-Centre of Studies on Geography and Spatial Planning, 4150-564 Porto, Portugal \\ 3 Department of Social, Political and Territorial Sciences, University of Aveiro, 3810-193 Aveiro, Portugal; \\ catarina.viana.costa@gmail.com \\ 4 CIPES-Research Center on Higher Education Policies, 4450-227 Matosinhos, Portugal \\ * Correspondence: sara.diogo@ua.pt
}

Received: 6 July 2018; Accepted: 31 July 2018; Published: 2 August 2018

\begin{abstract}
Aging populations pose a challenge to many policy areas. Although the importance of the built environment on citizens' mobility and quality of life has been widely acknowledged in the literature, research focusing on elderly people is relatively recent and still scarce namely in Portugal. This article aims at understanding how local stakeholders perceive the built environment and occupational activities targeted to the elderly. The article focuses on the municipality of Viseu, a medium-sized city located in the NUTSII Centro Region of Portugal, considered twice to be the best city to live in in Portugal. Document analysis and face-to-face semi-structured interviews of local stakeholders were conducted. Findings show that there is still a need to take further policy steps to allow older adults to be more active and to promote the neighbourhood's walkability.
\end{abstract}

Keywords: local policies; old-aged people; built environment; walkable environment; activities

\section{Introduction}

Biological changes that lead to functional degeneration are visible in the way old-aged people perform daily tasks [1]. As such, an increasing focus on the promotion of health, wellness, and quality of life amongst particularly this set of population, including physical activity, has been proved beneficial [2,3]. In fact, in the words of Peeters, Gardiner, Dobson, and Brown (2017) [4], "in older adults, physical inactivity is associated with a range of chronic conditions". Still, many old-aged people have a sedentary lifestyle. This invests pedestrian mobility of great importance, as it is the activity that most elderly do, as a natural and intentional movement, and being easy to perform just as a simple way of moving, as a sports practice and even as a leisure activity [5-9].

Pedestrian mobility can be either enhanced or inhibited by internal (e.g., biological and clinical) or external factors (e.g., build environment, existence or nonexistence of activities). Public policies can play a key role on this matter, creating conditions (tangible and intangible) that encourage the use of public spaces, thereby contributing to improve senior's health, wellbeing, and quality of life [9-11]. In this sense, the scientific community and policy makers need to be aware of how this challenge is being tackled in different contexts in order to learn from good and bad practices.

This study stems from the importance of this topic for policy makers and municipalities as well as a way to contribute to increase the knowledge regarding the relationship between pedestrian mobility, built environment, and inducing activities for older people mobility. This approach derives also from the fact that such lack of studies is particularly visible in the Portuguese context, which justifies addressing these issues in a specific local context [12]. The overall objective of this 
paper is to understand if and how local public policies promote walkable environments for the elderly. Speck refers that [13] a walkable environment must be useful (in which all aspects of daily life are located close), safe (well protected from getting hit by automobiles), comfortable (with no urban mobility barriers), and attractive to people. In this sense, we are interested in grasping how such policies can create actions directly targeted to the built environment, while considering strategies promoting activities for the elderly that stimulate both their physical and pedestrian activities.

The empirical component of the research lays on an exploratory case-study design with a qualitative approach developed in the city of Viseu, located in NUTSII Centro Region of Portugal. In 2012, a study conducted by the Portuguese consumer protection magazine [14] labelled Viseu as the best city to live in Portugal, following the same ranking position obtained in 2007, hence providing an excellent case to analyse how such a highly ranked place considers the issue at stake. Part of the result was due to several characteristics and factors linked to walkable environments.

Based on document analysis and semi-structured face-to-face interviews to a sample of local administration and non-governmental organisations' key actors, the present study attempts to answer the following research questions: how is the built environment thought and designed in order to take into account older people mobility restrictions? How are local activities promoting the mobility of older people?

This article begins by focusing on the conceptual framework that guides the study: health, physical activity, aging, pedestrian mobility, and the built environment. After a brief literature review on such topics, attention is paid to the role of local public policies in this matter. Following this theoretical and conceptual approach, the characterisation and analysis of the empirical study is provided, followed by the discussion of the findings. Finally, conclusions are drawn, as an attempt to form a learning vehicle for forthcoming studies in this domain and for policy makers.

\section{Health, Physical Activity and Aging}

According to Mallinson (2002) [15] and Bryant (1995) [16], health is probably one of the best examples of a non-consensual concept and, as such, usually wrapped in discussion. There is, still, a widespread perception that health should be considered as the greatest resource for social, economic, and personal development, being intimately related to the quality of life. In turn, quality of life is a result of different forms of interaction with the environment [17].

Promoting health requires a set of values, such as life, solidarity, equity, democracy, citizenship, and participation, amongst others. But it also requires the combination of strategies and government actions (in which public and healthy policies are included), of community actions (the strengthening of community activities), of individual actions (the development of personal skills), of the health care system (for the reorientation of this sector), and intersectoral partnerships [18].

The Portuguese Directorate-General for Health [2] states that physical activity is essential to the quality of life, health, and wellbeing, for that the human body was generated to move, hence being paramount to optimise its performance and to prevent disease. According to Sundquist et al. (2011) [19], physical activity is associated with a number of positive health outcomes, such as increased longevity and decreased risks of cardiovascular disease, diabetes mellitus type 2 , and some types of cancer. Not surprisingly, the relationship between physical activity and quality of life in what particularly concerns the case of the elderly has been gaining especial attention in the scientific community, being an enhancer element of the changes that arise naturally with aging [20-22]. Hygiene and health care promotion measures, which consequently impact on life expectancy, imply that all social and economic consequences of the aging process are taken into consideration [1].

Faced with this challenge, societies and, in particular, health care organisations acknowledge the need of creating health, participation and security conditions that strengthen the quality of life of old-aged people [1,2]. 


\section{Pedestrian Mobility and Built Environment}

Out-of-home walking is necessary for accessing commodities, making use of neighbourhood facilities, and participate in social, cultural, and physical activities [23,24]. As such, walking is frequently prescribed as a therapeutic activity for older people, considering that it is a natural and intentional movement, easily performed and which has evidenced good results in promoting health and wellbeing, and in enhancing physical and mental fitness [5-7], walking works as a way to move, even just to the closest or most convenient stopover for using public transportation, considering that very often seniors can no longer drive or have access to a private transport [8].

Due to mobility decline, old-aged people tend to lose autonomy $[25,26]$. Consequently, this has an impact on the quality and quantity of performed daily activities, which become fewer and more poorly executed. This leads to a potential increase or a greater risk of experiencing depression or falling, being the latter situation identified as one of the major causes of morbidity and mortality among the elderly $[7,27,28]$.

The benefits for health and physical and mental wellbeing derived from walking are widely acknowledged $[19,26]$. Still, the magnitude of these benefits and advantages depends largely on the distance, time and energy spent, pace of walking, and even on the individual characteristics [29]. In fact, there are factors that condition or imply more or less mobility and which represent an important element of the quality of life pursued by people [30]. However, the strength, endurance, balance, vision and hearing tend to decline with age, increasing physical weakness, and restraining walks in the neighbourhood, for example. It is in this context that Ross, Schmidt and Ball (2013) [7] state that the built environment has a huge impact on old-aged people.

This being said, a built environment that considers a specific population such as the elderly is inevitably one that will also be of use to the general population, providing that, at any period of life, all individuals are likely to experience some incapacity (whether permanent or temporary) [30]. As a matter of fact, quiet environments with well-connected streets, good access to potential destinations, environmental characteristics, attractiveness, safety, and comfort, are all factors which influence old-aged people when they choose to walk $[21,29,31]$. This is in line with the neighbourhood walkability concept as suggested by Sundquist et al. (2011) [19] and the Speck (2012) [13] rationale for walkable environments. As such, spaces without physical constraints to mobility are not the only condition or an isolated factor to induce mobility. The easiness with which people move is related to the way the built environment supports and encourages pedestrian activity, and which considers determinant factors of comfort, safety and destinations' supply.

The positive characteristics of built environments-in which the spatial organisation of services and pedestrian mobility have great impact-are determinant factors for the quality of life of old-aged people [12]. According to Santinha and Marques (2013) [12], two crucial aspects must be considered: (i) services' location and their relationship, availability, features, and diversity in neighbourhoods; (ii) walking mobility as a conditioning factor of greater or lesser suitability of the space and for promoting essential activities to people. Also, on this matter, and more specifically with respect to the location of services, Carstens (1993) [32] and Goodman and Tolley (2003) [33] argue that essential basic services should be located at a $400 \mathrm{~m}$, where people take on average five minutes to reach this distance. For other types of services, $800 \mathrm{~m}$ distance should be considered, spending twice the time to walk that distance. More recently, Burton and Mitchell (2006) [34] argue that the estimation of the walking time associated to these distances was made based on a non-elderly population. According to the authors, one should add 10 and 20 min respectively to the previous time needed to walk the aforementioned distances. Other factors, such as quality, continuity and convenience, for instance, should also be considered during the design of the built environment, and need to be taken into account when formulating policies capable of promoting pedestrian mobility [35]. After a thoughtful analysis of the studies published by the aforementioned scholars, the main factors related to the characteristics considered necessary to encourage pedestrian mobility on the old-aged population were agglomerated as illustrated in Table 1. 
Table 1. Factors of the built environment (Aveiro, Portugal 2016).

\begin{tabular}{|c|c|c|}
\hline Factors & Definition & Components (Examples) \\
\hline Irradiation & $\begin{array}{l}\text { The maximum amount of time that } \\
\text { citizens take to travel from the place } \\
\text { they are originally located to their } \\
\text { destination by foot or using public } \\
\text { transportation }\end{array}$ & $\begin{array}{l}\Rightarrow \quad \text { Location and distance to services/activities: } \\
\text { - } \quad \text { no further than } 400 / 500 \mathrm{~m} \text { from primary services } \\
\text { (health centre, green spaces, etc.), within a walking } \\
\text { time of } 10 \text {-min } \\
\text { - no further than } 800 \mathrm{~m} \text { from the secondary services } \\
\text { (open spaces, leisure activities, etc.), within a } \\
\text { walking time of } 20 \text {-min }\end{array}$ \\
\hline Connectivity & $\begin{array}{l}\text { The extent to which the pedestrian } \\
\text { network is continuous, without } \\
\text { barriers, and connected to } \\
\text { main 'attractors' }\end{array}$ & $\begin{array}{ll}\Rightarrow \quad \begin{array}{l}\text { Density, size of quarters/blocks, and number } \\
\text { of intersections }\end{array} \\
\Rightarrow \quad \text { Natural barriers and topographic impacts } \\
\Rightarrow \quad \text { Location of the services/activities } \\
\Rightarrow \quad \text { Connection between modes of transportation }\end{array}$ \\
\hline Conspicuous & $\begin{array}{l}\text { The existence of 'inviting' features in } \\
\text { the public space; variety and safety, } \\
\text { promoting social interaction }\end{array}$ & $\begin{array}{ll}\Rightarrow & \text { Visual interest of the built environment } \\
\Rightarrow & \text { Security } \\
\Rightarrow & \text { Social relationships } \\
\Rightarrow & \text { Attractiveness factors }\end{array}$ \\
\hline Suitability/Convenience & $\begin{array}{l}\text { The extent to which walking routes } \\
\text { are direct, combining footpaths, } \\
\text { sidewalks, mixed roads with } \\
\text { moderate traffic, crosswalks and } \\
\text { underground passages, as well as } \\
\text { pedestrian zones }\end{array}$ & $\begin{array}{ll}\Rightarrow & \text { Distance to the services/activities } \\
\Rightarrow & \text { Alternative paths } \\
\Rightarrow & \text { Crossings } \\
\Rightarrow & \text { Useful/clear width (space and function) }\end{array}$ \\
\hline Readability & $\begin{array}{l}\text { The extent to which roads and public } \\
\text { spaces are easy to be identifiable by } \\
\text { elderly people }\end{array}$ & $\begin{array}{ll}\Rightarrow & \text { Information } \\
\Rightarrow & \text { Explicit and visible signs } \\
\Rightarrow & \text { Architectural diversity of materials and colours } \\
\Rightarrow & \text { Striking, differentiating, and familiar elements }\end{array}$ \\
\hline Comfort & $\begin{array}{l}\text { The extent to which public spaces and } \\
\text { pedestrian routes provide people to } \\
\text { enjoy a full and pleasant mobility, } \\
\text { without restrictions of space or } \\
\text { barriers, as well as an attractive design }\end{array}$ & $\begin{array}{ll}\Rightarrow & \text { Architectural and urban barriers } \\
\Rightarrow & \text { Pedestrian paths / flows } \\
\Rightarrow & \text { Lighting and street furniture } \\
\Rightarrow & \text { Health and resting structures }\end{array}$ \\
\hline
\end{tabular}

Source: authors' elaboration based on literature review.

As already mentioned, a built environment with no urban barriers and constraints for citizens is a necessary but not sufficient condition to promote pedestrian mobility. As such, it is important to fully grasp which type of activities may induce the mobility of old-aged people; accordingly, one needs to understand the main drivers or motivations that lead this specific group of people to perform activities in their community that range from simply walking to practicing sports [36]. In this context, it is crucial for the design of public policies to integrate an overall vision combining the physical or material perspective (built environment) with the immaterial or intangible perspective (activities).

\section{Local Public Policies in the Relationship of Physical Activity, Aging, Pedestrian Mobility and Built Environment}

Public policy constitutes every permanent and comprehensive action of the public power (at the national and local levels) in a given area of activity, in which one adopts strategies to deal with problems previously identified and materialized by principles, guidelines, goals (of short, medium, and long term), and explicit standards set through plans, programmes and projects (Souza 2006). More than a sum of initiatives, often displayed in a fragmented way, public policies should form a coherent set of actions with short, medium, and long-term goals for which the necessary means to achieve them are mobilized [34]. Measures seeking to create environmental, socioeconomic, and cultural conditions beneficial to the individual and collective health should contribute to make it easier for citizens to 
make healthy choices, making them more accessible to everyone. People with special needs expect that all existing mechanisms and instruments available and needed for the creation of a barrier-free environment will be used. They also expect awareness and involvement from the population in general and from the necessary agents [37].

Amidst the demographic changes, and after the European Parliament and the European Commission declared the year 2012 as the "European Year of Active Ageing and Solidarity between generations", Portugal committed to develop several initiatives that seek to stimulate the debate, the exchange of good practices and the public awareness for cultural change, boosting relevant dynamics in the field of fundamental human rights, e.g., appealing discrimination on the grounds of age, promoting justice, social protection, and values of solidarity between generations [38].

Pedestrian mobility is one of the most potential ways of moving as it involves a small investment, especially in physical infrastructures. As such, it should have renewed attention from policies focusing on the built environment [8]. Local authorities have a wide panoply of good practices that they can put into practice to enhance pedestrian mobility, namely: to change mentalities and processes, to correct and change mistakes, to involve local actors, to establish intervening partnerships, as well as to raise the population's awareness for mobility practices or their absence [11,39]. A good example of best practices is given by the Global Guide of Age-friendly Cities, published by the World Health Organisation (WHO) in 2009 [11], and which provides guidelines for the development of environments that set conditions regarding the needs and preferences of old-aged people. This document has served as a model for municipalities, helping them to map their position regarding practices in this domain (World Health Organization 2009) [11]. In Portugal, there are municipalities sensitive to these areas and concerned in analysing the parameters listed in the WHO guide, in order to study and implement what is possible and feasible in a given context. An illustrative example of this analysis is the work of Centeio et al. (2010) [40] for the city of Aveiro, which sought to investigate the positive and negative aspects of this city, identifying the factors that can be improved for allowing an increasingly active aging process.

The Cidades project, promoted by the association VIDA, is another example of an attempt to translate the 2009 guide into the actual Portuguese context. Based on the aspects proposed by the global guide, this project tried to encourage all Portuguese municipalities to establish a dialogue with citizens over 55 years old in order to assess the friendliness of the municipality where they live (World Health Organization 2009) [11]. The results, however, are global and not specific to each city. Furthermore, the surveys were merely directed to the elderly, not encompassing the vision of decision-makers, hence not acknowledging the fact that local authorities can act on these issues, designing and implementing policies targeted to the built environment, while simultaneously, through a synergistic and interpreted manner, promote policies to induce physical and pedestrian activities among seniors. These activities are those that have produced proven benefits for the elderly and that motivated (directly or indirectly) walking mobility. In fact, several authors (see inter alia [8, $40,41]$ ) identify examples of such physical activities that, when practiced frequently by the elderly, have physical benefits in health and wellbeing. Also mental activities incite cognitive stimulation, wellbeing, and lower risks of developing depressions and/or other diseases. Occupation and leisure activities, social, as well as productive (senior work) and civic activities (senior volunteer and civic activism) breed personal benefits derived from keeping social networks, physical, and mental, as well as from wellbeing and quality of life.

\section{Methodology}

The empirical part of this research takes place in the district of Viseu. Being located in NUTS II Centro region of Portugal and NUTS III Dão Lafões-which spans for 14 municipalities, covering an area of more than $3.488 \mathrm{~km}^{2}$-the municipality of Viseu has approximately 100,000 inhabitants, of which almost $20 \%$ are over 65 years old. Viseu is the third largest city of the Centro Region of Portugal [41]. 
Due to the nature of the research object, the empirical work followed an exploratory study with a qualitative approach. A case-study approach was used as a method of inquiry-this revealed to be a rich methodology from the perspective of the depth of information research and also useful to understanding conceptual and contextual contours that are not yet properly defined and grounded [42]. Data collection was based on document analysis followed by semi-structured interviews, allowing for a better structure of the dialogue between the interviewer and the interviewee, while simultaneously giving the chance to the interviewer to think and elaborate on other topics that were not previously taken into consideration [42]. The interviews were conducted face to face to key actors selected from a non-random rational sample, featuring the research objectives initially outlined. Eight interviews were carried out: six to local public authorities (city council and parish councils) and the others to social entities, namely to one private institution of social solidarity (IPSS) and to a district council church (parish priest). The choice of actors as well as the definition of the interview guideline emerged from the conceptual framework and sought to analyse a concrete reality (district of Viseu) according to the perceptions of those who take political decisions or may have an effective participation in decision-making processes. Such an option allowed to better understand if local public policies and actions promoted in fact walkable environments for old-aged people.

All interviews were recorded with the due consent of respondents and they last, on average, about an hour. They were fully transcribed and submitted to a comparative and descriptive content analysis procedure. Thus, for each of the following dimensions of analysis-(i) Built Environment, Old-aged People, and Pedestrian Mobility; (ii) Activities for Old-aged People and Pedestrian Mobility - the aim was to understand how the built environment is perceived by the interviewees, which factors should be considered in each policy area or domain of action and also which policies should be developed to address the weaknesses while leveraging potentialities.

\section{Findings}

The first analytical comment relates to the way respondents perceived the topics under discussion. In the beginning of each interview, it was notorious a certain discomfort from some respondents to talk about the issue at stake, as they felt somehow distant from the topic, and also due to the fact that they considered, in a first moment, the subject did not fall within their competences. For example, one of the interviewees mentioned-“I am not sure how helpful this interview can be for you as I am not familiar with this topic". As such, there was the need to act as an ice-breaker and to explain in more depth the context and the spheres of action, as well as some policies related to the study. On this, we also felt the need to clarify some key and meaningful words/expressions to some of the respondents. This shows that there is a lack of familiarity with the more technical aspects that characterise and frame the research object. It is worth noticing that the youngest interviewees and with a higher level of training and education showed more interest towards the topics of analysis. From this, we can infer that more literacy and/or a higher level of education can lead to more sensitivity and subsequent actions to these issues, and/or also that the younger population is more aware of such themes.

With respect to the specific case of the elderly walking mobility, and its relationship with the built environment, the actors mostly focused on the accessibility conditions for physical activity. Only later, alongside the discussion of the topic, interviewees connected the pedestrian mobility issue with other domains of action, in particular related to convenience, readability, interaction, and convivial, evidencing some openness from actors to these issues.

The debate on these topics applied to the specific case of Viseu showed that there is a general awareness of key features of this municipality, focusing on the improvements made in the built environment that facilitate and support the elderly, which shows a real concern to solve remaining problems and weaknesses at this level. The following statement is an example extracted from the discussion with one of the interviewees that clearly shows the improvement that has been done in this domain: 
"We have a lot of pedestrian circuits, but it is a job that is still in progress and we really want to create some more paths ... to make them here, between the larger buildings for public use where people can ride bicycles and walk, with priority and safety along the path."

In this context, it was referred that public policy decisions on these issues emerge mostly as a reaction to the community complaints regarding (un)existing events and/or occurrences, which may be indicative of the lack of a predefined strategy and, consequently, of a fragmented view of the situations. As one of the interviewees argued, "policy-making is the exercise of what is possible". This attitude of respondents suggests some sensitivity towards the issues related with the built environment from a general perspective (community), and not so much directed to the pedestrian mobility and elderly issues. In fact, the discussion tended to focus on this general topic of public policy intervention, as the following argument given by one interviewee illustrates:

"The easiness that the city council provides combined with safe lighting, (...) the cycle path is a fabulous example: every day thousands of people walk in the cycle path. And a large percentage of them... well, it can be said that they are elderly"

Worth mentioning is that interviewees' opinions converge on the fact that many adaptations were carried out in relation to the built environment, impelling a need for constant maintenance of all these adaptations. In other words, as the built environment was not designed providing a walkable environment, there is a constant need to renew and adapt existing public spaces and sidewalks.

From an institutional point of view, one should notice that for most of the interviewees local authorities are the ones who must be responsible for the intervention in these areas. In fact, one of the interviewees was very clear on this subject:

"The location of the main services with an already established Spatial Master Plan which already defines the rules and where to install the services/infrastructures (...) for example, industrial parks, industries that are targeted to certain places, the historical centre is more appropriated to other types of places; in areas that are expanding and also urban areas more related with lodging issues with some type of business and locating large infrastructures, e.g., the Hospital, the Polytechnic. These have to obey to the licensing and permission of the City Council, being defined according to the capacity and access conditions of the place, a set of factors so that afterwards they do not harm the environment nor cause constraints. This is why I think they are fundamental and obviously because people will have a high level of accessibility. It does not make sense to build a large hospital and then not have access to it, not have transportation or an environment that supports such factors".

It is also worth mentioning that respondents recognised the lack of knowledge they have about the (spatial) location of some services, pointing and assuming the need to develop studies with professional experts on such areas of intervention.

After discussing the built environment, the next topic concerned the activities that promote more mobility among the elderly population. On this, interviewees classified the city council of Viseu as the main promoter of municipal activities. Almost absent from the interviewees' discourse was the important role other organisations have on this theme, as for example the private institutions of social solidarity and the Santa Casa da Misericórdia (Saint Mercy House).

In turn, interviewees pointed to the existence of some programmes and projects in the municipality that stand out within the domain of physical, occupational, recreational, and of social interaction activities for the elderly. Among these programmes, the Senior Activity programme that mobilises all these typologies of activities was highlighted.

Following this, respondents referred to the importance of fostering physical and intellectual activities, not only because they contribute to increased health and wellbeing, but also because they believe that the practice of one activity benefits the other, working as a kind of symbiotic relationship. 
Worth mentioning though that civic, social, and productive activities were only referenced after the presentation and explanation of some of these concepts during the interviews. However, there is still a long path to undertake in this domain:

“There isn't any productive activity, but I wish it existed! (...) We live in a country steeped in bureaucracy, a type of bureaucracy that everything that one does has a cost. If, at least, there were incentives from the state to promote more and a better life, incentives that could go from professional activity to the moment people retire, at the entrepreneurship level. (...) If a person wants to do something, he or she should be able to do it, and the government could do a valid job, to improve citizens' quality of life. But this is not easy... Unfortunately we live in a country where this is not stimulated".

On the other hand, there is the need to instigate more awareness in local stakeholders, as they showed scarce know-how about the different typologies of activities. Sometimes respondents even changed their arguments during the interview, as the following example shows:

"First, intellectual activities, followed by civic and productive ones. Social and physical activities are not considered a priority" (priorities later changed by the interviewee, arguing that) "for the elderly people, the main activities should be physical and mental or psychological ones".

Most respondents stressed the indirect stimulus that exists for walking, since there are several types of activities that lead to this practice. Examples include hiking, the senior activity, the sporty mornings, and all types of physical and intellectual activities designed and sponsored by the municipality, considering that all of them involve, at least, pedestrian mobility.

The type of actions considered more urgent to put into practice, according to most respondents, relate to the strong need for social cohesion and attractiveness in order to deal with the problem of desertification seen mostly in peripheral areas. However, although physical activities are classified as the most relevant during the discourses, when asked about the types of activities that they consider to be the most important, the reaction of most actors is not immediate or spontaneous, pointing later to intellectual, civic, and productive activities. From an analytical viewpoint, this reveals, once more, scant sensitivity to the concepts and to the relevance of the various typologies of activities.

In order to tackle the weaknesses associated to the typology of activities and to enhance the potentials that have been identified, it is considered of paramount importance that, increasingly more, one acts directly on the needs felt by the population. In addition, one must develop inclusive policies for the most vulnerable segments of societies' active life, such the elderly, as the population in deed is ageing- “ ( ... ) policies targeting older people, I think, are related to this new societal challenge", as stated by a stakeholder.

Bearing in mind the comments made by the respondents, it was possible to identify policies that can be developed concerning the activities mentioned. It was considered decisive to implement actions related to all types of activities, i.e., not only to focus on physical activities, but also to develop intellectual, civic, social, and productive activities, as this panoply stands for various proven benefits for people's health and wellbeing. In this way, and looking at the advantages that this case study shows, one can infer the possibility of extending the activities already in place to the more rural and semi-urban areas. On such topic, one of the respondents argued the following:

"For a city to adapt to the issues of reduced mobility of the elderly, it may have to invest millions, so this is funding that usually is applied within cities over time. So, you see... if it takes time for the cities to adapt, imagine what happens in peripheral areas".

We could also attest that it is crucial to raise awareness about the advantages these activities bring, so that people can more easily and with more confidence adhere to the activities. In this sense, it is 
important to involve the population in general and seek for solutions in a proactive way according to their needs.

Finally, from an institutional perspective, and as opposed to respondents' perspectives during the discussion regarding the built environment, interviewees highlighted the need for a broader participation of organisations in this field of action. In fact, a governance approach was claimed by local stakeholders. This is very much in line with the concept presented by Santinha [12], stating that "governance focuses on consultation and participation processes, in which policies are developed through mobilization of a variety of actors so that objectives are reached through collaboration instead of authority". Though recognising that it is still insufficient, the project Senior Activity, coordinated by the City Council to promote active ageing, was mentioned as a good example of such collaborative approach:

"The Senior Activity project is pioneering and innovative, involving more than two thousand people: the 25 parishes and several institutions that carry out activities. Besides sport, there are studies promoted by the School of Education, the health part is accompanied by the ACES-Dão Lafões and also in the part of consumer protection".

\section{Discussion}

The empirical work shows a constant adaptation and concern by the municipality with the built environment, mainly in the urban context, and particularly regarding the architectural and urban barriers that prevent pedestrian mobility. It is acknowledged the great need to implement policies at the level of the various dimensions of the built environment, both to rural and semi urban areas. Simultaneously, it was clear that decision-makers should be aware that walkable environments include more than just considering the built environment features per se. Readability, connectivity, convenience, and conviviality are some of the dimensions to take into account as well. Such observations are similar to the ones published by Patla and Shumway-Cook (1998) [43] and Shumway-Cook et al. (2002) [44], stating that requirements associated with community mobility are complex and go beyond the physical features.

Local actors tend to adopt a fragmented and narrowed vision of the relationship between the built environment and senior citizens' social activities. In this sense, the idea of carrying out training actions to address this weakness, creating moments of debate and analysis of good practices implemented in other municipalities may be worth trying. The study published by Shumway-Cook et al. (2002) [44] not only presents similar results but also call attention for an additional factor: the importance of designing intervention programs that train older adults to modify gait in response to numerous environmental challenges likely to be encountered in the community. This is particularly important for older people with some degree of disability as reinforced by Pahor et al. (2014) [45]. In fact, due to functional decline in late life, health education strategies together with such intervention programmes can work in a complementary way to individual centred interventions typically used by healthcare providers (Satariano and McAuley, 2003) [46].

It was also noticed in our study that the responsibility of intervention in the domains analysed (built environment and activities) is mostly attributed to the local government. This signals that little importance is given to other possible and potential actors in the design of public policies in such fields of action. In this way, it is important to develop moments for a proper discussion to set up tasks, priorities and commitments on this. Thus, both in the construction of new built environments and in the requalification of already existing spaces, the municipality must create formal and informal dialogue settings with various local actors in order to find joint solutions to the identified needs and problems. Several authors have underlined the importance of creating formal and informal dialogue sceneries regarding the relationship between the elderly and mobility. For instance, Rosenbloom (2004) [24] states that in response to the growing number of older people it is paramount to understand how they interact with their family and friends in ways that influence their activity choices and transportation needs. Following the same rationale, Santariano et al. (2012) [47] proposes an integrated 
mobility agenda to face the ageing challenges and create a stronger foundation for more comprehensive and effective practices and mobility policies.

With respect to the activities designed to old-aged people and to promote pedestrian mobility, the municipality of Viseu highly focus on physical activities, figuring as pioneer of the "senior activity", comprising already all the parishes of the municipality - a fact that attests the success of this project. Similar results emphasising the promotion of the mobility of the elderly people through the design of suitable infrastructures and the development of physical activities were found in the study developed by Centeio et al. (2010) [40] for the city of Aveiro, Portugal. However, physical activities are not the only ones that matter. As the theoretical framework of this article showed, intellectual, civic, social, and productive activities that are considered less important by the respondents and which are not fully developed in the municipality should be promoted. The results of study published by Ogilvie et al. (2007) [48] reinforce this observation, arguing that various approaches must be offered to older people as different types of people may respond to different approaches, tailored to their psychological characteristics or life circumstances.

Although interviewees acknowledged the fact that they should not apply policies without considering (local) partners and organisations, this case study attested that this does not always happen. According to interviewees, the decision is made mostly on a case-by-case basis, contrary to what conceptually is argued - that it should be based on the technical component and considering stakeholders' engagement and dialogue. In this sense, the delegation of tasks from the central government to local governments, and from these to the parish councils (which are closer to the communities), would constitute a strategy to continuously develop activities and involve people. It should, however, be highlighted that the municipality is aware of the importance of applying and extend good practices to the most vulnerable populations.

With respect to public policies, one needs to understand what are the criteria applied for decision-making and for the enactment of actions or policies targeted to the elderly. At this stage, we verify that it is not possible to identify a standard pattern without a joint strategy formulated previously, including the citizens' perspective. As Ståhl et al. (2008) argue [49], older people, in their capacity as users and consumers with the right to express their opinions, are interesting and useful partners for policy-making and delivery. As such, a cooperative planning process involving the elderly, the local authorities, and other stakeholders is vital to promote the elderly people's engagement with outdoor environments, not only nurture participation in physical activities, but also to support social interaction with the community.

Although interviewees are familiar with many examples of success, all of them stated that the municipality of Viseu stands out as a successful reference. The main reason pointed for this is the great concern with social inclusion, through the constant adaptation of public places to the more vulnerable segments of the population.

Tables 2 and 3 summarise the interviewees' perspective explained above. Table 2 focus on what is being done regarding the built environment and what still needs to be improved from a policy viewpoint. For most of the interviewees, to provide safe, efficient, and visually appealing public spaces and surrounding environments to citizens, and accordingly promote older people's mobility, should be a priority, despite acknowledging that it may be more expensive than immaterial interventions. On the other hand, Table 3 tackles the less obvious policies, but equally important in the interviewees' opinion: what policies are promoting activities for the elderly and what is still missing in this domain. 
Table 2. Viseu and the built environment: from what is being done to what is needed (Aveiro, Portugal 2016).

\begin{tabular}{|c|c|c|c|}
\hline What Needs Improvement & Present Policies & Needed Policies & Operational Perspective \\
\hline Urban barriers mainly in peripheral areas & $\begin{array}{l}\text { Adapting and removing barriers } \\
\text { preventing access for all, whenever } \\
\text { possible and according to priorities } \\
\text { (reactive perspective) }\end{array}$ & $\begin{array}{l}\text { - } \quad \text { Systematic maintenance of public space } \\
\text { Extension of actions developed in the more } \\
\text { urban context for the peripheral areas. } \\
\text { Design of new spaces focusing on accessibility } \\
\text { criteria for all (proactive perspective). }\end{array}$ & $\begin{array}{l}\text { Carry on periodic evaluations of all interventions } \\
\text { performed with specialised technicians. } \\
\text { Extend the action focus to the parishes of the semi-urban } \\
\text { and rural contexts through the delegation of powers to the } \\
\text { presidents of the parish councils. } \\
\text { Develop internal rules for the use of universal design } \\
\text { criteria in public spaces in the municipality. }\end{array}$ \\
\hline $\begin{array}{l}\text { Urban Planning mainly focused on the } \\
\text { location of the services }\end{array}$ & $\begin{array}{l}\text { Definition of the location rules of } \\
\text { services by the Local Master Plan }\end{array}$ & $\begin{array}{l}\text { Update of the Local Master Plan considering all } \\
\text { components of the built environment. }\end{array}$ & $\begin{array}{l}\text { Use specialised professionals and studies for a more } \\
\text { comprehensive analysis of the built environment. }\end{array}$ \\
\hline $\begin{array}{l}\text { Reactive decision making and non-proactive } \\
\text { due to lack of resources }\end{array}$ & $\begin{array}{l}\text { Management of places promoting } \\
\text { walking and cycling paths and tours }\end{array}$ & $\begin{array}{l}\text { - Maintenance of existing spaces through a wider } \\
\text { perspective (e.g., safety, lighting and absence } \\
\text { of obstacles). } \\
\text { Application of structure, safety, comfort, } \\
\text { and attractiveness norms in existing and } \\
\text { future routes. }\end{array}$ & $\begin{array}{l}\text { Develop strategies for adapting existing routes to specific } \\
\text { pedestrian corridors } \\
\text { Link existing footpaths and visible signs. } \\
\text { - Create properly identified bicycle and pedestrian corridors } \\
\text { with signs and maps available to people. } \\
\text { Acting upon the attractiveness of spaces. }\end{array}$ \\
\hline
\end{tabular}

Source: authors' elaboration based on the interviews.

Table 3. Viseu and activities for the elderly: from what is being done to what is needed (Aveiro, Portugal 2016).

\begin{tabular}{|c|c|c|c|}
\hline What Needs Improvement & Present Policies & Needed Policies & Operational Perspective \\
\hline $\begin{array}{l}\text { Existing social cohesion and } \\
\text { attractiveness still insufficient to } \\
\text { counteract desertification of places and } \\
\text { inland parishes }\end{array}$ & $\begin{array}{l}\text { Development of activities to involve } \\
\text { people from peripheral areas to settle in } \\
\text { these locations }\end{array}$ & $\begin{array}{l}\text { Diversification of the activities' supply and } \\
\text { involvement of people from various contexts. }\end{array}$ & $\begin{array}{ll}\text { - } & \text { Make a survey of the activities the population wish to } \\
\text { have/to do. } \\
\text { - }\end{array}$ \\
\hline Absence of productive activities & $\begin{array}{l}\text { Promotion of some specific civic and } \\
\text { social activities }\end{array}$ & $\begin{array}{l}\text { Promotion of productive, civic and social } \\
\text { activities for the population of the various } \\
\text { spatial contexts (urban-rural). }\end{array}$ & $\begin{array}{l}\text { Discuss with the central administration possible solutions } \\
\text { (initiatives and financing) in cooperation with } \\
\text { local stakeholders. } \\
\text { Identify strategies to stimulate productive, civic, and social } \\
\text { activities with the various local stakeholders. }\end{array}$ \\
\hline $\begin{array}{l}\text { Several types of activities developed but } \\
\text { still with little dissemination, e.g., } \\
\text { walking paths, senior activity, and sports }\end{array}$ & $\begin{array}{l}\text { Promotion of projects for the elderly, } \\
\text { with the senior activity being exclusive } \\
\text { to this population }\end{array}$ & $\begin{array}{l}\text { Dissemination of activities and encouragement } \\
\text { to participation among the elderly population. } \\
\text { Awareness-raising of people through thematic } \\
\text { events on health issues, including aspects of } \\
\text { physical and mental well-being. }\end{array}$ & $\begin{array}{l}\text { - Show and disseminate the benefits of each activity to } \\
\text { the population. } \\
\text { Define action plans with regard to monitoring the health } \\
\text { status of participants. }\end{array}$ \\
\hline
\end{tabular}




\section{Conclusions}

As the world is ageing rapidly, there is an increasing need for knowledge and evidence-based policy to cope with the challenges of such phenomenon. Maintaining independence and ensuring an active life as people age have been in the forefront of many governments' initiatives. All too often, though, the debate is focused on the management of health in older adults and accordingly on the rehabilitation of sensory functions to prevent falls and decline in mobility. However, external factors also impact older peoples' independence. In fact, the built environment may accelerate seniors' mobility decline and prevent their independence. As such, understanding which factors may affect outdoor mobility in old-aged citizens is useful to identify strategies and design policies to planning environments and activities that motivate inclusive communities and prevent mobility decline.

This study allows us to both understand and identify some weaknesses and potentialities to which policy makers should pay more attention in order to adopt an integrated perspective between the built environment and activities for senior citizens. The analysis was based on a case study approach and focused on a municipality which, in the last decade, was considered twice the best place to live in Portugal. Still, findings show that the typical approach taken by the municipality aims mainly at solving immediate problems, according to the existing possibilities and resources. Simply put, interventions are established in a reactive way and not thought in a proactive manner.

Studies of this nature should be extended to other realities, as they will be useful to assess whether these arguments can be generalized. If so, it is important to design a general framework of public policies that effectively consider the issue of pedestrian mobility and its relationship with the built environment, assembled with the development of activities targeted to the elderly population. Such approach could enable a range of actors, namely the local governments, to develop ageing programmes tailored to each territorial context and, accordingly, embed age-friendliness in local thinking and recognise older people as active citizens.

A final note should be left to point to one of the limitations of this study. In this paper, we have tried to raise attention to the importance of decision-makers in designing the built environment (also) according to an elderly population. However, policymakers should not merely plan "for" the people but also "with" the people-in this case the elderly. The exploratory nature of the study, the deadlines and the objectives initially proposed dictated the choice of not including the voices of this group. However, in order to partly overcome this issue, the perspective of entities that deal on a daily basis with this segment of the population and which are quite aware of their concerns was included in the empirical study.

Author Contributions: All authors were actively involved in the elaboration of this article. The main idea and its conceptualization were conceived by the first two authors G.S. and C.M. and it was later on discussed with the third author S.D. The empirical data was collected and analysed by the first two authors, and validated later by the third author. During writing the original draft the first author did most of the preparation, supported by the other authors. Re-writing, revising, and editing were mostly the third author's responsibility, although the first and second authors also contributed.

Funding: This research received no external funding.

Conflicts of Interest: The authors declare no conflict of interest.

\section{References}

1. Paúl, C.; Ribeiro, O. Manual de Gerontologia; Lidel: Lisboa, Portugal, 2012.

2. Direção-Geral da Saúde, D.G.S. A Actividade Física e o Desporto: Um Meio Para Melhorar a Saúde e o Bem-Estar; Serviço Nacional de Saúde: Lisboa, Portugal, 2007.

3. Webber, S.C.; Porter, M.M.; Menec, V.H. Mobility in older adults: A comprehensive framework. Gerontologist 2010, 50, 443-450. [CrossRef] [PubMed]

4. Peeters, G.M.; Gardiner, P.A.; Dobson, A.J.; Brown, W.J. Associations between physical activity, medical costs and hospitalisations in older Australian women: Results from the Australian Longitudinal Study on Women's Health. J. Sci. Med. Sport 2017. [CrossRef] [PubMed] 
5. Isaacson, M.; D'Ambrosio, L.; Samanta, T.; Coughlin, J. Life-Stage and Mobility: An Exploratory GPS Study of Mobility in Multigenerational Families, Ahmedabad, India. J. Aging Soc. Policy 2015, 27, 348-363. [CrossRef] [PubMed]

6. Gatrell, A.C. Therapeutic mobilities: Walking and 'steps' to wellbeing and health. Health Place 2013, 22, 98-106. [CrossRef] [PubMed]

7. Ross, L.A.; Schmidt, E.L.; Ball, K. Interventions to maintain mobility: What works? Accid. Anal. Prev. 2013, 61, 167-196. [CrossRef] [PubMed]

8. Seabra, M.; Pinheiro, A.; Marcelino, C.; Santos, D.; Leitão, J.; Patronilho, L. Acessibilidades, Mobilidade e Transportes Nos Planos Municipais de Ordenamento Do Território-Guião Orientador; Instituto da Mobilidade e dos Transportes Terrestres: Lisboa, Portugal, 2011.

9. World Health Organization. Active Ageing: A Policy Framework; WHO: Genebra, Switzerland, 2002.

10. George, F. Sobre os Determinantes da Saúde_-Texto Adaptado e Resumido Baseado na Publicação Intitulada "Histórias de Saúde Pública; Livros Horizonte: Lisboa, Portugal, 2004.

11. World Health Organization. Global Age-Friendly Cities: A Guide; WHO: Genebra, Switzerland, 2009.

12. Santinha, G.; Marques, S. Repensando o fenômeno do envelhecimento na agenda política das cidades: A importância da promoção da mobilidade de pedestres. [Rethinking the phenomenon of aging in the cities' political agenda: The importance of promoting pedestrian mobility]. Rev. Bras. Geriatr. Gerontol. 2013, 16, 393-400. [CrossRef]

13. Speck, J. Walkable City: How Downtown Can Save America, One Step at a Time; Farrar, Straus and Giroux: New York, NY, USA, 2012.

14. DECO PROTESTE. Melhores Cidades Para Viver. In Família e Consumo: Férias e Lazer; 2012. Available online: https:/ / www.deco.proteste.pt/familia-consumo/ferias-lazer/noticias/melhores-cidades-paraviver (accessed on 9 April 2018).

15. Mallinson, S. Listening to respondents: A qualitative assessment of the Short-Form 36 Health Status Questionnaire. Soc. Sci. Med. 2002, 54, 11-21. [CrossRef]

16. Bryant, C.G.A. Practical Sociology: Post-Empiricism and the Reconstruction of Theory and Application; Polity Press: Cambridge, UK, 1995.

17. Martinoni, M.; Sartoris, A. Criteria for the Elderly People City? Simplify the Complexity to Act in Concrete Terms. In Proceedings of the International Conference of City Futures in a Globalising World, Madrid, Spain, 4-6 June 2009.

18. Ottawa, C. 1986. Ottawa Charter for Health Promotion. In Proceedings of the First International Conference on Health Promotion, Ottawa, ON, Canada, 21 November 1986.

19. Sundquist, K.; Eriksson, U.; Kawakami, N.; Skog, L.; Ohlsson, H.; Arvidsson, D. Neighborhood walkability, physical activity, and walking behavior: The Swedish Neighborhood and Physical Activity (SNAP) study. Soc. Sci. Med. 2011, 72, 1266-1273. [CrossRef] [PubMed]

20. Matsudo, S.M.; Matsudo, V.K.R.; Neto, T.L.B. Atividade física e envelhecimento: Aspectos epidemiológicos. Rev. Bras. Med. Esporte 2001, 7, 2-13. [CrossRef]

21. Van Holle, V.; Van Cauwenberg, J.; Van Dyck, D.; Deforche, B.; Van de Weghe, N.; De Bourdeaudhuij, I. Relationship between neighborhood walkability and older adults' physical activity: Results from the Belgian Environmental Physical Activity Study in Seniors (BEPAS Seniors). Int. J. Behav. Nutr. Phys. Act. 2014, 11, 110. [CrossRef] [PubMed]

22. Lotfi, S.; Koohsari, M.J. Neighborhood walkability in a city within a developing country. J. Urban Plan. Dev. 2011, 137, 402-408. [CrossRef]

23. Rantanen, T. Promoting Mobility in Older People. J. Prev. Med. Public Health 2013, 46 (Suppl. 1), S50-S54. [CrossRef] [PubMed]

24. Rosenbloom, S. Mobility of the elderly: Good news and bad news. In Transportation in an Aging Society: A Decade of Experience; Transportation Research Board: Washington, DC, USA, 2004; pp. 3-21.

25. Horner, M.W.; Duncan, M.D.; Wood, B.S.; Valdez-Torres, Y.; Stansbury, C. Do aging populations have differential accessibility to activities? Analyzing the spatial structure of social, professional, and business opportunities. Travel Behav. Soc. 2015, 2, 182-191. [CrossRef]

26. Beck, A.P.; Antes, D.L.; Meurer, S.T.; Benedetti, T.R.R.; Lopes, M.A. Factors associated with falls among elderly practitioners of physical activities. Texto Contexto-Enferm. 2011, 20, 280-286. [CrossRef] 
27. Rubenstein, L.Z. Falls in older people: Epidemiology, risk factors and strategies for prevention. Age Ageing 2006, 35 (Suppl. 2), Ii37-Ii41. [CrossRef] [PubMed]

28. C3 Collaborating for Health. The Benefits of Regular Walking for Health, Well-Being and the Environment; C3 Collaborating for Health: London, UK, 2012.

29. Araújo, M.R.M.D.; Oliveira, J.M.D.; Jesus, M.S.D.; Sá, N.R.D.; Santos, P.A.C.D.; Lima, T.C. Transporte público coletivo: Discutindo acessibilidade, mobilidade e qualidade de vida. Psicol. Soc. 2011, 23, 574-582. [CrossRef]

30. Borst, H.C.; Henk, M.E.; Miedema, S.I.; de Vries, J.; Graham, A.; van Dongen, J.E.F. Relationships between street characteristics and perceived attractiveness for walking reported by elderly people. J. Environ. Psychol. 2008, 28, 353-361. [CrossRef]

31. Carstens, D.Y. Site Planning and Design for the Elderly: Issues, Guidelines, and Alternatives; John Wiley \& Sons: Hoboken, NI, USA, 1993.

32. Goodman, R.; Tolley, R. The Decline of Everyday Walking in the UK: Explanations and Policy Implications; Woodhead Publishing: Sawston/Cambridge, UK, 2003.

33. Burton, E.; Mitchell, L. Inclusive Urban Design: Streets for Life; Elsevier: New York, NY, USA, 2006.

34. Stein, E.M.; Tommasi, K.; Lora, E.E.; Payne, M. Banco Interamericano de Desenvolvimento: A Politica Das Políticas Públicas-Relatório; Elsevier: New York, NY, USA, 2006.

35. Ribeiro, J.; Cavalli, A.; Cavalli, M.; Pogorzelski, L.; Prestes, M.; Ricardo, L. Adesão de Idosos a Programas de Atividade Física: Motivação e Significância. Rev. Bras. Ciência e Esporte 2012, 34, 969-984. [CrossRef]

36. Souza, C. Políticas públicas: Uma revisão da literatura. Sociologias 2006, 8, 20-45. [CrossRef]

37. Teles, P. Cidades de Desejo Entre Desenhos de Cidades: Boas Práticas de Desenho Urbano e Design Inclusivo; Instituto de Cidades e Vilas com Mobilidade: Porto, Portugal, 2009.

38. Governo de Portugal. Ano Europeu Do Envelhecimento Ativo e Da Solidariedade Entre Gerações. 2012. Available online: http:/ / www.europarl.europa.eu/news/pt/headlines/eu-affairs/20120106STO34946/2012ano-europeu-do-envelhecimento-activo-e-da-solidariedade-entre-geracoes (accessed on 11 April 2018).

39. Centeio, H.; Dias, S.; Rito, S.; Santinha, G.; Vicente, H.; Sousa, L. Aveiro: Cidade amiga das pessoas idosas. Rev. Bras. Geriatr. Gerontol. 2010, 13, 369-381. [CrossRef]

40. Ribeiro, O. O envelhecimento "ativo" e os constrangimentos da sua definição. Sociologia Revista da Faculdade de Letras da Universidade do Porto 2012, 2, 33-52.

41. PORDATA. Dados Estatísticos Sobre o Município de Viseu. 2015. Available online: https:/ /www.pordata. pt/Municipios (accessed on 25 May 2018).

42. Martins, R. Os Idosos e as Actividades de Lazer; Instituto Politécnico de Viseu: Viseu, Portugal, 2010; pp. $243-251$.

43. Patla, A.E.; Shumway-Cook, A. Dimensions of mobility: Defining the complexity and difficulty associated with community mobility. J. Aging Phys. Act. 1998, 7, 7-19. [CrossRef]

44. Shumway-Cook, A.; Patla, A.E.; Stewart, A.; Ferrucci, L.; Ciol, M.A.; Guralnik, J.M. Environmental demands associated with community mobility in older adults with and without mobility disabilities. Phys. Ther. 2002, 82, 670-681. [PubMed]

45. Pahor, M.; Guralnik, J.M.; Manini, T.M.; Guralnik, J.M.; Ambrosius, W.T.; Espeland, M.A.; Kritchevsky, S.B.; Newman, A.B. Effect of structured physical activity on prevention of major mobility disability in older adults: The LIFE study randomized clinical trial. JAMA 2014, 311, 2387-2396. [CrossRef] [PubMed]

46. Satariano, W.A.; McAuley, E. Promoting physical activity among older adults: From ecology to the individual. Am. J. Prev. Med. 2003, 25 (Suppl. 2), 184-192. [CrossRef]

47. Satariano, W.A.; Guralnik, J.M.; Jackson, R.J.; Marottoli, R.A.; Phelan, E.A.; Prohaska, T.R. Mobility and aging: New directions for public health action. Am. J. Public Health 2012, 102, 1508-1515. [CrossRef] [PubMed]

48. Ogilvie, D.; Foster, C.E.; Rothnie, H.; Cavill, N.; Hamilton, V.; Fitzsimons, C.F.; Mutrie, N. Interventions to promote walking: Systematic review. BMJ 2007, 334, 1204. [CrossRef] [PubMed]

49. Stahl, A.; Carlsson, G.; Hovbrandt, P.; Iwarsson, S. "Let's go for a walk!": Identification and prioritisation of accessibility and safety measures involving elderly people in a residential area. Eur. J. Ageing 2008, 5, 265-273. [CrossRef] [PubMed]

(C) 2018 by the authors. Licensee MDPI, Basel, Switzerland. This article is an open access article distributed under the terms and conditions of the Creative Commons Attribution (CC BY) license (http:/ / creativecommons.org/licenses/by/4.0/). 